\title{
HUBUNGAN ANTARA KARAKTER MANDIRI BELAJAR DENGAN HASIL BELAJAR SISWA
}

\author{
Fadillah Rahmayani \\ Fakultas Keguruan dan Ilmu Pendidikan, Universitas Jambi \\ email: fadillahrahmayani82@gmail.com
}

\begin{abstract}
The purpose of this research was to identify the relationship between independent learning characters and student learning outcomes. The population of this research was students of class XI MIPA Muaro Jambi 1 High School. The sample of this research was determined by total sampling technique which was 66 students. This research is a quantitative descriptive research that is with the technique of collecting data by questionnaires and tests. Questionnaires are used to collect independent students learning data and tests are used to determine learning outcomes. The data analysis technique used is Pearson Correlation to see how the relationship between students' independent character and learning outcomes. Data analysis was performed by SPSS Statistics 25 Software. From the results of the analysis data obtained, the Pearson correlation was 0.891 so the correlation was in the high category. Therefore, it can be concluded that the Character of Mandiri Learning has a relationship with student learning outcomes.
\end{abstract}

Keyword: Independent Character, Learning Outcomes

Abstrak: Tujuan penelitian ini adalah untuk mengidentifikasi hubungan antara karakter mandiri belajar dengan hasil belajar siswa. Populasi penelitian ini adalah siswa kelas XI MIPA SMA Negeri 1 Muaro Jambi. Sampel penelitian ini ditentukan dengan teknik total sampling yaitu sebanyak 66 siswa. Penelitian ini merupakan penelitian deskriptif kuantitatif yakni dengan teknik pengumpulan data secara penyebaran angket dan tes. Angket digunakan untuk mengumpulkan data mandiri belajar siswa dan tes digunakan untuk mengetahui hasil belajar. Teknik analisis data yang digunakan adalah Korelasi Pearson untuk melihat bagaimana hubungan atau keterkaitan antara karakter mandiri siswa dengan perolehan hasil belajar. Analisis data dilakukan dengan Software SPSS Statistic 25. Dari hasil analisis data yang diperoleh yakni pearson correlation-nya sebesar adalah 0,891 sehingga korelasinya termasuk kategori tinggi. Oleh karena itu dapat disimpulkan bahwa Karakter Mandiri Belajar memiliki hubungan dengan Hasil Belajar siswa.

Kata kunci: Karakter Mandiri, Hasil Belajar

\section{PENDAHULUAN}

Kualitas SDM bangsa ditentukan oleh tingkat pendidikan dalam Negara itu sendiri hal ini dikarenakan jika semakin tinggi kualitas dari sumber daya manusianya maka Negara tersebut akan semakin meningkat pula efisiensi dan produktivitasnya. Hal ini sesuai dengan yang dikemukakan oleh Sari and Kadri (2018) bahwa Pendidikan adalah suatu sarana penting untuk meningkatkan kualitas sumber daya manusia (SDM) yang mana peningkatan kualitas sumber daya manusia jauh lebih mendesak untuk segera direalisasikan saat ini.Hal tersebut juga sesuai dengan yang dikemukakan oleh Atmanti (2005) bahwa Pendidikan yang lebih tinggi akan memperluas ilmu pengetahuan masyarakat dan memungkinkan masyarakat untuk mengambil langkah-langkah lebih rasional dalam hal mengambil suatu keputusan. Pendidikan merupakan bentuk kegiatan yang sangat dibutuhkan bagi seluruh umat manusia pada saat ini,hal ini dikarenakan dengan dengan adanya 
pendidikan manusia dapat merubah perilaku dan pengetahuan menjadi lebih baik Hal ini sejalan dengan yang tertera pada Undang Undang Republik Indonesia Nomor 20 tahun 2003 tentang sistem pendidikan nasional, bahwa pendidikan adalah usaha sadar terencana untuk mewujudkan suasana belajar dan proses pembelajaran agar peserta didik secara aktif mengembangkan potensi dirinya untuk memiliki kekuatan spiritual keagamaan, pengendalian diri, kepribadian, kecerdasan, akhlak mulia, serta keterampilan yang diperlukan dirinya, masyarakat, bangsa dan Negara. Pendidikan itu sendiri meliputi banyak cabang ilmu pengetahuan, salah satu diantaranya adalah ilmu Fisika.

Salah satu cabang dari ilmu pengetahuan adalah ilmu Sains. Menurut Martaida et.al (2018), Sains merupakan pengetahuan yang diperoleh melalui pembelajaran dan pembuktian. Fisika merupakan bagian dari sains yang pada hakikatnya adalah proses, produk dan sikap. Ilmu Fisika merupakan suatu cabang ilmu pengetahuan yang mempelajari mengenai perubahan gejala alam dan interaksi yang terjadi. Sejalan dengan Giancoli (2014) bahwa Fisika merupakan ilmu sains yang berintegrasi dengan perilaku dan gejalagejala fenomena alam yang dikaitkan dengan fenomena sekarang atau yang terjadi saat ini. Maison et.al (2018) juga mengungkapkan bahwa Fisika adalah salah satu mata pelajaran mengenai konsepkonsep ilmiah yang dapat diterapkan dalam kehidupan sehari-hari. Selain itu, Menurut Azizah (2015) 'Pembelajaran Fisika memiliki tujuan mengembangkan pengetahuan, pemahaman, dan kemampuan analisis siswa terhadap lingkungan sekitarnya dan dalam belajar fisika siswa tidak hanya mesti menguasai konsep tetapi juga menerapkan konsep tersebut'. Pernyataan tersebut juga sejalan dengan yang dikemukakan oleh Bhakti and Napis (2018) bahwa Dalam proses pembelajaran fisika, siswa tidak hanya sekadar menghafal teori dan rumus, akan tetapi lebih ditekankan pada terbentuknya proses pengetahuan dan penguasaan konsep.
Pada kenyataannya, setiap pembelajaran Fisika merupakan suatu mata pelajaran yang tidak terlalu disenangi dan bahkan ditakuti oleh peserta didik. Hal tersebut sejalan dengan yang dikemukakan Purwanto (2012) bahwa mata pelajaran fisika umumnya dikenal dengan mata pelajaan yang ditakuti dan tidak disukai murid-murid karena biasanya bermula dari pengalaman belajar mereka yang mana mereka menemukan kenyataan bahwa pelajaran fisika adalah pelajaran berat dan serius. Hal ini tentunya akan mempengaruhi prestasi hasil belajar siswa tersebut.

Dalam pendidikan dan dalam pembelajaran siswa dituntut untuk memiliki perilaku mandiri dikarenakan memiliki sikap mandiri merupakan salah satu tujuan pembelajaran layaknya yang dikemukakan oleh Permendiknas No. 22 tahun 2006 tentang Standar Isi menyatakan bahwa IPAFisika bukan hanya memiliki sumbangan nyata terhadap perkembangan teknologi, IPA-Fisika mendidik siswa di dalam pembelajarannya untuk bertindak atas dasar pemikiran yang kritis, yang analitis, yang logis, yang rasional, yang cermat dan sistematis, serta menanamkan kebiasaan berpikir dan berperilaku ilmiah yang kritis, kreatif dan mandiri. Menurut Yunginger (2008) bahwa, 'siswa diharapkan aktif belajar secara mandiri dalam interaksi belajar mengajar fisika, aktivitas belajar mandiri di antaranya aktivitas pandang, aktivitas lisan, aktivitas dengar, aktivitas tulis, aktivitas gerak, dan aktivitas emosional'.

Mandiri dalam belajar itu sendiri merupakan suatu hal yang sangat penting dalam proses pembelajaran dikarenakan Mandiri dalam belajar berpengaruh terhadap hasil prestasi belajar siswa tersebut. Hal ini sejalan dengan hasil penelitian Wahyudi (2011) bahwa Mandiri belajar memiliki kontribusi yang positif dan signifikan terhadap prestasi belajar siswa. Susilawati (2009) mendeskrepsikan mengenai mandiri belajar yakni diantaranya: (1) Siswa berusaha untuk meningkatkan tanggung jawab dalam mengambil berbagai keputusan, (2) Mandiri dipandang sebagai suatu sifat yang sudah ada pada setiap orang dan situasi 
pembelajaran, (3) Mandiri bukan berarti memisahkankan diri dari orang lain, (4) Pembelajaran mandiri dapat mentransfer hasil belajarnya yang berupa pengetahuan dan keterampilan dalam berbagai situasi, (5) Siswa yang belajar mandiri dapat melibatkan berbagai sumber daya dan aktivitas seperti membaca sendiri, belajar kelompok, latihan dan kegiatan korespondensi, (6) Peran efektif guru dalam belajar mandiri masih dimungkinkan seperti berdialog dengan siswa, mencari sumber, mengevaluasi hasil dan mengembangkan berfikir kritis dan (7) Beberapa institusi pendidikan menemukan cara untuk mengembangkanbelajar mandiri melalui program pembelajaran terbuka.

Berdasarkan uraian tersebut oleh karena itu dilakukanlah penelitian ini yang mana tujuan dari penelitian ini adalah untuk mengidentifikasi hubungan antara karakter mandiri belajar dengan perolehan hasil belajar siswa.

\section{METODE PENELITIAN}

Penelitian ini dilakukan di SMA Negeri 1 Muaro Jambi. Pada penelitian ini peneliti menunjukkan mengenai hubungan karakter mandiri dengan hasil belajar dalam pembelajaran fisika siswa kelas XI. Peneliti mengumpulkan fakta tentang karakter mandiri siswa dalam pembelajaran fisika dengan metode penelitian yang digunakan berupa metode penelitian kuantitatif korelasi.

Teknik pengumpulan data yang digunakan dalam penelitian ini adalah angket dan tes. Angket digunakan untuk mengumpulkan data mandiri belajar siswa dan tes digunakan untuk mengetahui hasil belajar. Angket yang digunakan tersebut diadopsi dari Skripsi Purnamasari (2013). Angket tersebut telah divalidasi dan terdiri dari 25 butir pertanyaan. Dengan menggunakan 4 skala pengukuran. Skala tersebut yaitu Sangat Sering (SS) diberi skor 4, Sering (S) diberi skor 3, Kadangkadang (KK) diberi skor 2 dan Tidak Pernah (TP) diberi skor 1 . Sedangkan untuk soal Tes digunakan 30 Butir soal yang mana untuk hasil akhirnya diberi penilaian jika Benar bernilai 1 (satu) dan jika salah bernilai 0 (nol).
Populasi penelitian adalah siswa kelas XI MIPA di SMA Negeri 1 Muaro Jambi. Peneliti menggunakan teknik pengambilan sampel yaitu total sampling. Hal ini dikarenakan dalam penelitian ini populasi sekaligus sebagai sampel penelitian.

Setelah data dari seluruh responden terkumpul selanjutnya data dianalisis untuk mengetahui ada tidaknya pengaruh mandiri belajar terhadap hasil belajar siswa. Teknik analisis data yang digunakan adalah melakukan uji prasyarat analisis yaitu uji normalitas, dan uji linearitas.

\section{Uji Normalitas}

Menurut Ranti et.al (2017), Uji normalitas dilakukan untuk mengetahui apakah dalam model regresi, variabel pengganggu atau residual memiliki distribusi normal. Model regresi yang baik adalah memiliki distribusi data normal atau mendekati data normal atau tidak. Uji normalitas pada penelitian ini menggunakan uji Kolmogorov-smirnov dan dengan ketentuan:

1) Jika sig $<0,05$ maka data tidak normal

2) Jika sig $>0,05$ maka data dikatakan normal.

\section{Uji Linearitas}

Uji linearitas dilakukan untuk mengetahui apakah dua variabel tersebut memiliki hubungan yang linear atau tidak secara signifikan. Jika nilai Sig > 0,05 maka data yang digunakan dapat dijelaskan oleh regresi linier.

\section{Uji Korelasi}

Korelasi digunakan untuk mengetahui derajat pengaruh antara variabel bebas dan variable terikat. Uji Korelasi yang digunakan dalam penelitian ini adalah korelasi Pearson Product Moment (PPM).

Pengujian data di sini dilakukan dengan pengujian menggunakan bantuan aplikasi SPSS.

\section{HASIL DAN PEMBAHASAN}

Permasalahan yang dideskripsikan dalam penelitian ini mengenai bagaimana pengaruh dari karakter Mandiri siswa 
terhadap hasil belajar dalam pembelajaran Fisika. Mandiri belajar merupakan mandiri seseorang dalam kegiatan belajarnya. Mandiri belajar mendorong seseorang mengambil pronsip segala aspek kegiatan belajar. Mandiri belajar secara mandiri terwujud dalam penentuan tujuan, keteraturan serta kesungguhan mendalami bahan pelajaran dalam memilih metode serta sarana, disiplin dengan aturan dan perencanaan dan berinisiatif untuk meningkatkan prestasi belajarnya, percaya diri dan optimis terhadap hasil yang dicapai serta tanggung jawab (Wahyudi, 2011).

Berdasarkan hasil pengisian angket mandiri belajar, diperoleh rata-rata mandiri belajar Siswa di SMA Negeri 1 Muaro Jambi. Berikut deskripsi mandiri Siswa per kategori:

Tabel 1. Mandiri belajar siswa

\begin{tabular}{llll}
\hline Skor & Kategori & f & Persentasie (\%) \\
\hline $25-43,75$ & Tidak Pernah & 0 & 0 \\
$43,75-62,5$ & Kadang-Kadang & 0 & 0 \\
$62,5-81,25$ & Sering & 58 & 87,9 \\
$81,25-100$ & Sangat Sering & 8 & 12,1 \\
\hline Jumlah & & 66 & 100 \\
\hline
\end{tabular}

Berdasarkan penggolongan penerapan karakter kemandirian siswa responden pada Tabel 1 diatas dapat dilihat data menunjukkan bahwa pada indikator yang diajukan cendrung berada pada kategori Sering. Persentase Karater Mandiri siswa disekolah ini dari rentang 25-43,75 kategori tidak pernah persentasenya sebesar $0 \%$. Pada rentang 43,75-62,5 kategori
Kadang-Kadang persentasenya sebesar 0\%, pada rentang 62,5-81,25 kategori Sering persentasenya sebesar $87,9 \%$ dan pada rentang 81,25-100 kategori Sangat Sering persentasenya sebesar $12,1 \%$ dengan jumlah siswa 66 orang.

Selanjutnya untuk data dari hasil belajar diperoleh data sebagai berikut:

Tabel 2. Hasil Belajar Siswa

\begin{tabular}{llll}
\hline Skor & Kategori & f & Persentasie (\%) \\
\hline $0-7,5$ & Kurang & 1 & 1,5 \\
$7,5-15$ & Cukup & 9 & 13,6 \\
$15-22,5$ & Baik & 37 & 56,1 \\
$22,5-30$ & Sangat Baik & 19 & 28,8 \\
\hline Jumlah & & 66 & 100 \\
\hline
\end{tabular}

Berdasarkan Tabel 2 penggolongan hasil belajar siswa dapat dilihat bahwa Persentase hasil belajar siswa disekolah ini dari rentang skor 0-7,5 kategori 'Kurang' persentasenya sebesar $1,5 \%$. Pada rentang skor 7,5-15 kategori 'Cukup' persentasenya sebesar $13,6 \%$, pada rentang skor $15-22,5$ kategori 'Baik' persentasenya sebesar $56,1 \%$ dan pada rentang skor 22,5-30 kategori 'Sangat Baik' persentasenya sebesar 28,8\% dengan jumlah siswa 66 orang dan frekuensi $100 \%$.
Selanjutnya data tersebut dianalisis untuk mengetahui apakah terdapat pengaruh mandiri belajar terhadap hasil belajar siswa dengan menggunakan Uji Korelasi Pearson, namun sebelum itu dilakukan dulu uji normalitas dan Linearitas.

\section{Hasil Uji Normalitas}

Dengan menggunakan bantuan SPSS, diperolehlah data hasil sebagai berikut 
Tabel 3 Test of Normality Angket

\begin{tabular}{|c|c|c|c|c|c|c|}
\hline \multirow{3}{*}{ 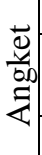 } & \multicolumn{3}{|c|}{ Kolmogorov- Smirnov ${ }^{\mathrm{a}}$} & \multicolumn{3}{|c|}{ Shapiro-Wilk } \\
\hline & $\begin{array}{l}\text { Statisti } \\
\text { c }\end{array}$ & $\mathrm{df}$ & Sig & $\begin{array}{l}\text { statist } \\
\text { ic }\end{array}$ & $\mathrm{Df}$ & Sig. \\
\hline &, 095 & 66 & 200 & ,978 & 66 & 285 \\
\hline
\end{tabular}

Berdasarkan data table diatas dapat dilihat pada bagian tabel KolmogorovSmirnov. Pada tabel tersebut terdapat nilai Sig-nya adaah sebesar 0,200 yang mana hal ini berarti nilai Sig > 0,05 sehingga bisa dikatakan data tersebut terdistribusi normal.
Uji Linearitas

Dengan menggunakan bantuan SPSS, diperolehlah data hasil Uji Linearitas berupa Tabel ANOVA sebagai berikut:

Tabel 4 Hasil Uji Linearitas

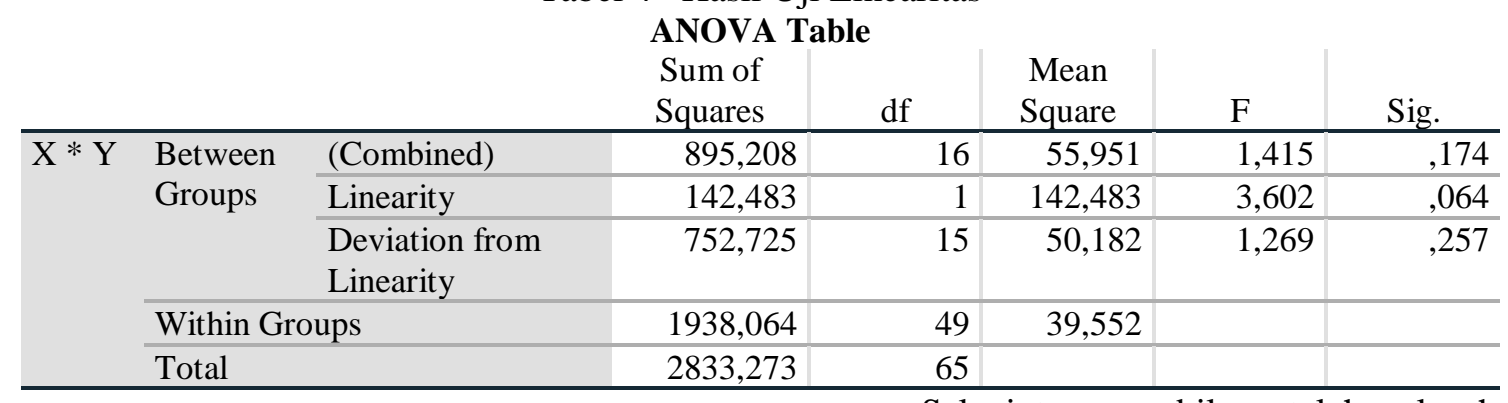

Berdasarkan hasil di atas, untuk mengetahui apakah data tersebut memenuhi uji linearitas, dilihat dari tabel Linearity diperoleh nilai Sig sebesar 0,064 yang berarti nilai Sig > 0,05 sehingga data yang digunakan dapat dijelaskan oleh regresi linier.
Selanjutnya apabila setelah seluruh persyaratan terpenuhi dilakukanlah $\mathrm{Uji}$ Korelasi Pearson untuk melihat hubungan antara Karakter Mandiri Belajar (X) dengan Hasil Belajar siswa (Y). Korelasi ini dilakukan juga menggunakan SPSS Statistic 25 yang mana diperoleh data hasil sebagai berikut:

Tabel 5 Hasil Uji Korelasi

\section{Correlations}

\begin{tabular}{llr|r} 
& & ANGKET & SOAL \\
\hline ANGKET & Pearson Correlation & 1 &, $891^{* *}$ \\
\cline { 2 - 4 } & Sig. (2-Tailed) & 66 &, 000 \\
\cline { 2 - 4 } & $\mathrm{N}$ &, $891^{* *}$ & 66 \\
\hline Hasil & Pearson Correlation &, 000 & 1 \\
\cline { 2 - 4 } Belajar & Sig. (2-Tailed) & 66 & 66 \\
\cline { 2 - 5 } & $\mathrm{N}$ & &
\end{tabular}

Berdasarkan tabel output diatas diketahui bahwa nilai Sig. (2-tailed) antara Angket dengan Soal adalah sebesar 0,000 < 0,05 , yang berarti terdapat korelasi yang signifikan antara variable Angket dengan Variabel Soal. Berdasarkan nilai r-hitung untuk hubungan angket dengan soal adalah sebesar 0,891 > r tabel 0,201 (r-tabel diperoleh dari tabel r-tabel dengan nilai $\mathrm{n}=66$ dan signifikansi 5\%), maka dapat disimpulkan ada hubungan atau korelasi antara variable angket dan soal. Selanjutnya berdasarkan tanda bintang dapat dilihat bahwa masing-masing variable yang dihubungkan memiliki dua tanda bintang $(* *)$, hal ini berarti terdapat korelasi antara variable yang dihubungkan dengan taraf signifikansi $5 \%$ atau 0,05 .

Berkenaan dengan hal tersebut dapat diketahui bahwa fleksibilitas antar variabel menyatakan bahwasanya mandiri belajar siswa memiliki hubungan yang signifikan 
terhadap hasil belajar atau prestasi siswa. Berdasarkan perolehan hasil penelitian hubungan mandiri belajar dengan hasil belajar siswa berbanding lurus atau dapat dikatakan positif (+), artinya semakin baik tingkat mandiri belajar seseorang, maka hasil belajar pun juga akan baik nantinya. Namun, Mandiri tidak sepenuhnya akan mempengaruhi hasil belajar siswa, terdapat juga hal lain yang akan mempengaruhi hal tersebut, Seperti yang dikemukakan oleh Saefullah, et al (2013) bahwa terdapat faktor-faktor lain yang mempengaruhi prestasi belajar yang diiraih siswa antara lain; tingkat kecerdasan, sarana dan prasarana pembelajaran, metode pembelajaran, cara belajar, dan faktor lainnya.

Secara umum untuk tingkat mandiri belajar ini harus ditingkatkan lagi, hal ini dikarenakan mandiri yang memiliki peran dalam meningkatkan mandiri siswa karena pada kenyataannya masih banyak siswasiswi yang tidak mandiri dalam kegiatan pembelajaran, hal ini dapat dilihat juga dari frequensi angket yang diperoleh masih banyak yang berada di kategori Sering, dan tidak seluruhnya berada dikategori Sangat sering. Berdasarkan hasil penelitian dilihat bahwa masih banyak siswa yang terdakang mencontek pada saat penyelesaian soal dan beberapa masih tidak dapat belajar secara mandiri. Hal ini terlihat dari faktanya yang mana masih sedikit siswa yang mempelajari materi belajar terlebih dahulu sebelum dipelajari pada saat kegiatan pembelajaran di sekolah dan siswa-siswa tersebut hanya menunggu apa yang akan dijelaskan oleh guru tanpa ingin mencari tahu secara mandiri. Siswa biasanya hanya belajar apabila ada tugas yang diberikan oleh guru atau pada aat ujian akan berlangsung. Selain hal tersebut, Pada saat belajarmengajar berlangsung siswa cenderung malas bertanya mengenai hal yang belum diketahui atau dipahaminya. Hal-hal tersebut tentunya akan mempengaruhi bagaimana tingkat mandiri siswa tersebut hal ini dikarenakan Mandiri dalam belajar itu sendiri merupakan suatu hal yang sangat penting dalam proses pembelajaran karena Mandiri dalam belajar berpengaruh terhadap hasil belajar siswa.
Penelitian ini dapat dikatakan sesuai dengan teori dan juga sejalan dengan penelitian-penelitian sejenis sebelumnya yang telah dilakukan. Seperti dengan hasil penelitian Wahyudi (2011) bahwa Mandiri belajar memiliki kontribusi yang positif dan signifikan terhadap prestasi belajar siswa dan Hasil penelitian yang dilakukan oleh Junjunan (2009) menyimpulkan bahwa mandiri belajar memiliki kontribusi yang positif dan signifikan terhadap prestasi belajar siswa.

\section{SIMPULAN}

Berdasarkan hasil penelitian, analisis data, dan pembahasan, maka dapat diambil kesimpulan bahwa Karakter mandiri pada seorang siswa dalam belajar memiliki hubungan atau pengaruh yang tinggi terhadap perolehan hasil belajar dimana dalam hal ini setelah dilakukan uji korelasi diperoleh korelasi sebesar ,891 dalam Korelasi Pearson. Oleh karena itulah secara keseluruhan mandiri siswa tersebut harus terus ditingkatkan, dikarenakan tingkat mandiri siswa itu sendiri akan mempengaruhi prestasi belajar dari siswa tersebut yang dibuktikan perolehan hasil data penelitian ini yang juga sejalan dengan beberapa penelitian yang telah dilakukan sebelumnya.

\section{DAFTAR RUJUKAN}

Atmanti, H. D. (2005) Investasi Sumber Daya Manusia Melalui Pendidikan. Jurnal Dinamika Pembangunan, 2(1), 30-39

Azizah, Rismatul et al (2015) Kesulitan pemecahan masalah fisika pada siswa SMA, 5(2)

Bhakti dan Napis (2018) Pengembangan Lembar Kerja Siswa Berbasis Guided Inquiry berbantuan Physics Interactive simulation. Jurnal Pendidikan Fisika, 7(2), 124-130

Departemen Pendidikan Nasional (2003) Undang-Undang RI No.20 tahun 2003, Tentang Sistem Pendidikan Nasional, Jakarta: Depdiknas 
Departemen Pendidikan Nasional (2006) Permendiknas No. 22 Tahun 2006, Tentang Standar Isi untuk Satuan Pendidikan Dasar dan Menengah. Jakarta: Depdiknas

Giancoli, D. C. (2014) Fisika: Prinsip dan Aplikasi Edisi ke 7 jilid 1. Jakarta: Erlangga

Junjunan, S. (2009) Kontribusi Gaya Belajar Dan Mandiri Belajar Terhadap Prestasi Belajar Matematika Siswa Sma Negeri di Kota Bandung: Studi Analisis Deskriptif Terhadap Siswa Sma Negeri Kelas XI Ipa Berdasarkan Cluster Di Kota Bandung Tahun Ajaran 2008/2009. Skripsi FPMIPA UPI Bandung: tidak diterbitkan.

Maison, A., et al (2018) Deskripsi sikap siswa SMA NEGERI pada pembelajaran fisika ,10(1), 162-167

Martaida, et.al (2018) Efek Model Pembeljaran Discovery terhadap kemampuan berpikir kritis dan hasil Belajar Kognitif Siswa SMP. Jurnal Pendidikan Fisika, 7(2),118-123

Purnamasari, Y. (2013) Pengaruh Model Pembelajaran Koopertif Tipe Teams Games-Tournament (TGT) terhadap kemandirian Belajar dan Peningkatan Kemampuan Penalaran dan Koneksi Matematika Peserta Didik. Skripsi (Tidak Diterbitkan), Jakarta: Universitas Terbuka

Purwanto, A. (2012) Kemampuan Berpikir Logis Siswa SMA Negeri 8 Kota Bengkulu dengan Menerapkan Model Inkuiri Terbimbing dalam Pembelajaran Fisika. Jurnal Exacta, 10(2)
Ranti et.al (2017) Pengaruh Mandiri Belajar (Self Regulated Learning) Terhadap Hasil Belajar Siswa Pada Mata Kuliah Struktur Aljabar. Math Didactic: Jurnal Pendidikan Matematika, 3(1), 75-83

Saefullah et.al (2013) Hubungan Antara Sikap Mandiri Belajar Dan Prestasi Belajar Siswa Kelas X Pada Pembelajaran Fisika Berbasis Portofolio. Jurnal Wahana Pendidikan Fisika, 26-36, ISSN: 2338-1027.

Sari dan Kadri (2018) Pengaruh Model Group Investigation Terhadap Pengetahuan Konseptual Pada Materi Pokok Suhu Dan Kalor Di Kelas XI Smk Muhammadiyah 8 Medan. Jurnal Pendidikan Fisika, 7(2), 7783

Susilawati, D. (2009) Upaya Meningkatkan Kemandirian Belajar dan Kemampuan Matematika. Skripsi (tidak diterbitkan). Yogyakarta: Universitas Negeri Yogyakarta

Wahyudi (2011) Analisis Kontribusi Sikap Ilmiah, Motivasi Belajar Dan Mandiri Belajar Terhadap Prestasi Belajar Siswa Prodi Pendidikan Fisika Stkip Pgri Pontianak. Jurnal Edukasi Matematika dan Sains, 1(2),20-31

Yunginger, R. (2008) Deskripsi Tentang Aktivitas Mandiri Siswa Pada Mata Pelajaran Fisika. Jurnal Penelitian dan Pendidikan, 5(1),64-69 
94 JURNAL PENDIDIKAN EDUTAMA, Vol.6, No.2 Juli 2019 